\title{
HUBUNGAN KOMPENSASI DENGAN KEPUASAN KERJA GURU PENDIDIK KHUSUS (GPK) SEKOLAH DASAR INKLUSIF DI KOTA PADANG
}

\author{
Harri Kurniawan ${ }^{1)}$ Devi Agustianti ${ }^{2)}$ \\ ${ }^{1}$ Fakultas Psikologi, Universitas Putra Indonesia "YPTK" Padang \\ Email : arikkurniawan17@gmail.com, deviagustianti80@gmail.com,
}

\begin{abstract}
This research was conducted on Special Educator Teachers (GPK) Inclusive Primary Schools in Padang City. The purpose of this study was to determine the relationship between compensation and job satisfaction of Teachers of Special Educators (GPK) Inclusive Primary Schools in the City of Padang. The sample selection technique in this study uses Sampling Random Sampling,random sampling which is atechnique regardless of the strata that exist in that population (Sugiyono, 2014). The sample in this study amounted to 78 people. Test the validity and reliability using Cronbach Alpha.The trial results show the validity coefficient in the scale of compensation from 0.309 to 0.811 while the reliability coefficient is 0.941. The results of the coefficient trial of the validity of the job satisfaction scale show from 0.301 to 0.755 with a reliability coefficient of 0.917 . Hypothesis test results show the magnitude of the correlation coefficient of 0.835 with a significant level $p=0,000$. It means that it can be concluded that there is a significant relationship between compensation and job satisfaction. Positive values indicate that the higher the compensation, the better the teacher's job satisfaction, and vice versa the lower the compensation, the worse the job satisfaction of the Special Educator Teacher (GPK). The effective contribution of the compensation variable to job satisfaction is $70 \%$.
\end{abstract}

Keywords: Job Satisfaction, Compensation, Special Teacher Educators (GPK)

\begin{abstract}
Abstrak
Penelitian ini dilakukan pada Guru Pendidik Khusus (GPK) Sekolah Dasar Inklusif di Kota Padang. Tujuan penelitian ini adalah untuk mengetahui hubungan antara kompensasi dengan kepuasan kerja Guru Pendidik Khusus (GPK) Sekolah Dasar Inklusif di Kota Padang. Teknik pemilihan sampel dalam penelitian ini menggunakan Sampling Random Sampling, yaitu teknik pengambilan sampel dilakukan secara acak tanpa memperhatikan strata yang ada dalam populasi itu (Sugiyono, 2014). Sampel dalam penelitian ini berjumlah 78 orang. Uji validitas dan reliabilitas menggunakan Alpha Cronbach.Hasil uji coba menunjukkan koefisien validitas pada skalakompensasi 0,309 sampai 0,811sedangkan koefisien reliabilitasnya sebesar 0,941 . Hasil uji coba koefisien validitas skala kepuasan kerja menunjukkan dari 0,301 sampai 0,755 dengan koefisien reliabilitasnya sebesar 0,917. Hasil uji hipotesis menunjukkan besarnya koefisien korelasi sebesar 0,835dengan taraf signifikan $\mathrm{p}=0,000$ Artinya dapat disimpulkan bahwa terdapat hubungan yang signifikan antara kompensasidengan kepuasan kerja. Nilai positif menunjukkan bahwa semakin tinggikompensasi maka semakin baik kepuasan kerja guru, begitu juga sebaliknya semakin rendah kompensasi maka semakin buruk kepuasan kerja Guru Pendidik Khusus (GPK). Adapun sumbangan efektif dari variabel kompensasi terhadap kepuasan kerja sebesar $70 \%$.
\end{abstract}

Kata kunci: Kepuasan Kerja, Kompensasi, Guru Pendidik Khusus (GPK)

\section{Pendahuluan}

Pendidikan merupakan kebutuhan manusia sepanjang hidupnya. Pendidikan selalu mendapatkan perhatian dari seluruh Bangsa dan Negara, sebab pendidikan menemukan kualitas sumber daya manusia yang dapat membangun bangsa dan negara untuk mencapai tujuan.Pendidikan formal yaitu pendidikan yang didapatkan melalui sekolah merupakan pendidikan yang harus didapatkan oleh anak didik. Anak yang harus mendapatkan pendidikan formal bukan hanya anak yang mempunyai kemampuan atau anak normal. Anak 
yang mempunyai kemampuan khusus (ABK) dan anak berbakat juga harus mendapatkan pendidikan sama halnya dengan anak normal (Khoiriyahdalam Pratiwi, 2015) ${ }^{[10]}$.Kepuasan kerja berhubungan erat dengan sikap guru pendidik khusus (GPK) terhadap pekerjaannya sendiri, situasi kerja, kerjasama antara guru sesama guru dan dengan muridnya. Kepuasan kerja merupakan sikap umum yang merupakan hasil dari beberapa sikap khusus terhadap faktor-faktor pekerjaan, penyesuaian diri dan hubungan sosial individual di luar kerja. Kepuasan kerja sebagai hasil keseluruhan dari derajat rasa suka atau tidak sukanya tenaga kerja terhadap berbagai aspek dari pekerjaannya. Jadi, kepuasan kerja mencerminkan sikap tenaga kerja terhadap pekerjaannya (Handoyo, 2013) ${ }^{[1]}$.Handoko (dalam Sutrisno, 2012) mengungkapkan kepuasan kerja adalah keadaan emosional yang menyenangkan atau tidak menyenangkan bagi para karyawan memandang pekerjaan mereka. Karyawan yang memiliki kepuasan kerja akan dapat bekerja dengan baik, penuh semangat, aktif dan dapat berprestasi lebih baik dari karyawan yang tidak memperoleh kepuasan kerja. Sebaliknya, karyawan yang tidak memperoleh kepuasan kerja tidak akan pernah mencapai kepuasan psikologis dan akhirnya akan timbul sikap atau tingkah laku negatif seperti menurunnya kinerja, membolos, berhenti dari perusahaan, dan sebagainya ${ }^{[7]}$. Faktor-faktor yang mempengaruhi kepuasan kerja adalah balas jasa yang adil dan layak, penempatan yang tepat dan sesuai dengan keahlian, berat-ringannya pekerjaan, suasana dan lingkungan pekerjaan, peralatan yang menunjang pelaksanaan pekerjaan, sikap pimpinan dalam memimpin, dan sifat pekerjaan monoton atau tidak (Hasibuan, 2011). Salah satu kunci yang mempengaruhi kepuasan kerja yakni balas jasa atau sering disebut dengan pemberian kompensasi ${ }^{[11]}$.Saydam dikutip Natoatmodjo (2009) mengungkapkan kompensasi dimaksudkan sebagai balas jasa (reward) perusahaan terhadap pengorbanan waktu, tenaga dan pikiran yang telah diberikan mereka kepada perusahaan ${ }^{[7]}$.Wibowo (2011) mengatakan kesalahan dalam menerapkan sistem kompensasi akan berakibat timbulnya demotivasi dan tidak adanya kepuasan kerja di kalangan pekerja Keyakinan bahwa karyawan yang puas akan membawa dampak yang baik bagi perusahaan, menjadikan kepuasan kerja sebagi hal yang diperhatikan perusahaan. Pemberian kompensasi kepada karyawan dapat memotivasi dan memberikan kepuasan $\operatorname{kerja}^{[7]}$.

Berdasarkan wawancara awal yang dilakukan oleh peneliti pada hari Senin tanggal 15 Mei 2018, diperoleh keterangan bahwa Guru Pendidik Khusus mengajar sudah berkisar antara 2 hingga 6 tahun. Dan Guru Pendidik Khusus saat ini merasa kurang diperhatikan oleh pemerintah dengan status mereka sebagai guru honorer sehingga semangat mereka menurun untuk bekerja dan tidak memperoleh kepuasan kerja dalam mencapai tujuan pendidikan. Hal tersebut timbul karena merasa gaji terlalu kecil dan tidak sesuai untuk seorang guru sehingga tidak adanya motivasi dalam menghasilkan kinerja yang efektif. Efeknya dalam melaksanakan tugasnya dalam pekerjaan saat ini tidak terlaksanakan kewajiban sebagai pengawas dan pendidik Anak Berkebutuhan Khusus (ABK), kurang profesional dalam bekerja, dan sering mengabaikan anak didiknya. Alasan yang mereka utarakan adalah karena hal hal menyangkut kompensasi atau gaji yang tidak sesuai dengan pekerjaan. Gaji yang mereka terima tidak sesuai dengan pekerjaan mereka serta diberikan pun dengan waktu yang lama, sehingga mereka tidak lagi bersemangat dalam bekerja. Guru pendidik khusus (GPK) di Kota Padang merupakan guru honorer disetiap Sekolah Dasar Inklusif di Kota Padang. Kita jelas mengetahui jika guru honorer mendapatkan gaji yang diterima 1 kali dalam 3 bulan dengan jumlah setengah dari gaji pengawai umumnya yang diterima setiap bulannya. Jelas saja dengan gaji yang minim tersebut mereka akan menambah tanggung jawab lain. Mereka juga mengatakan kebanyakan Guru Pendidik Khusus (GPK) mencari kesibukan lain untuk mendapatkan gaji lebih dari yang seharusnya dengan tidak hanya saja berperan tunggal dalam mengawasi Anak Berkebutuhan Khusus (ABK) namun banyak guru juga berperan ganda dalam sekolah minsalnya menjadi guru bidang studi sebagai guru pengajar mata pelajaran lain dan banyak menjadi wali kelas. Dengan hal tersebut, tentunya mereka akan mendapatkan gaji tambahan sesuai tanggung jawab lainnya sebagai guru. Tentu saja, hal tersebut jelas mereka tidak berfokus pada tanggung jawab pada Anak Berkebutuhan 
Khusus (GPK) saja disekolah, namun akan mempunyai pekerjaan lain sebagai pekerjaan tambahan untuk memperoleh gaji tambahan dari yang seharusnya diterima dan berefek dengan terabaikan nya anak didik sehingga progres dalam selama di sekolah reguler belum terpenuhi secara baik. Seharusnya terjadi dalam sekolah reguler, Anak Berkebutuhan Khusus (ABK) akan mampu mandiri dan kemajuan yang lebih baik disekolah umum, hal tersebut tentu dengan pengawasan yang baik dari guru pendidik khusus (GPK). Guru Pendidik Khusus (GPK) dalam pekerjaannya, tentunya mereka tidak memiliki kenyaman lagi dalam bekerja dengan gaji yang minim namun umumnya mereka mengungkapkan lebih banyak memilih bertahan sebagai guru pendidik khusus (GPK) dikarekan sulitnya mencari pekerjaan lain dan peluang pekerjaan yang sulit didapatkan dengan wilayah yang sama. Apalagi yang terjadi saat ini, umumnya setiap perusahaan akan merekrut karyawan dengan batas umur. Kenyataannya kebanyakan Guru Pendidik Khusus (GPK) tersebut telah melewati batas umur yang kebanyakan perusahaan tentukan. Untuk menjadi Pegawai Negeri Sipil (PNS) juga tidak mudah didapatkan dengan pesaing dan jumlah guru yang mulai banyak. Menurut mereka kebijakan Kompensasi selain memberikan imbalan atas pekerjaan yang dilakukan guru juga merupakan salah satu cara yang efektif untuk mempertahankan guru bidang tersebut dalam mengawasi Anak Berkebutuhan Khusus (ABK), oleh karena itu pemberian kompensasi perlu mendapat perhatian khusus dan dilaksanakan atas dasar kepentingan sekolah maupun kebutuhan guru, sehingga menghasilkan manfaat yang maksimal. Salah satu fungsi manajemen sumber daya manusia yang penting bagi guru adalah kompensasi. Dengan adanya kompensasi maka guru merasakan adanya suatu ikatan dengan tanggung jawabnya dalam mengawasi dan mendidik Anak Berkebutuhan Khusus (ABK).

Tujuan dalam penelitian ini adalah untuk mengujiapakah terdapathubungan antara kompensasi dengan kepuasan kerja guru pendidik khusus (GPK) pada sekolah dasar inklusif Di Kota Padang.

\section{Tinjauan Pustaka}

\subsection{Pengetian Kepuasan Kerja}

Hasibuan (dalam Kurniawan, 2018)mengatakan bahwa kepuasan kerja adalah sikap emosional yang menyenangkan dan mencintai pekerjaannya. Sikap ini dicerminkan oleh moral kerja, kedisiplinan, dan prestasi kerja dinikmati dalam pekerjaan, luar pekerjaan dan kombinasi dalam dan luar pekerjaan ${ }^{[8]}$.

Menurut Colquitt, dkk (dalam Wibowo, 2014) kepuasan kerja adalah tingkat perasaan menyenangkan yang diperoleh dari penilaian pekerjaan seseorang atau pengakaman kerja, dengan kata lain kepuasan kerja mencerminkan bagaimana kita merasakan tentang pekerjaan kita dan apa yang kita pikirkan tentang pekerjaan itu ${ }^{[16]}$.

\subsection{Dimensi Kepuasan Kerja}

Menurut Porter (dalam Savana,2018) ${ }^{[14]}$, terdapat lima dimensi kepuasan kerja adalah:

1) Pay

Sikap pekerja terhadap imbalan berupa gaji, upah, dan bonus yang diterimanya setelah membandingkan dengan rekan lain, baik yang ada didalam atau diluar organisasi.

2) Work It Self

Sikap pekerja terhadap karakteristik pekerjaan, seperti variasi keterampilan, identitas tugas, signifikansi, dan umpan balik bekerja.

3) Promotion

Kesempatan untuk maju atau berprestasi dalam jenjang karir.

4) Coworker 
Kesempatan untuk bekerja sama dengan pekerja yang lainnya, sehingga mereka dapat bertukar pikiran dan mendiskusikan masalah-masalah yang dihadapi dalam bekerja.

\section{5) Working Condition}

Mencakup semua aspek fisik kerja, psikologis kerja, dan peraturan kerja yang ada ditempat kerja.

\subsection{Kompensasi}

Menurut Kasmir (dalam Hasanah,2018) kompensasi merupakan balas jasa yang diberikan perusahaan kepada karyawannya, baik yang bersifat keuangan maupun non keuangan ${ }^{[4]}$.

\subsection{Komponen-komponen Kompensasi}

Menurut Kasmir (dalam Hasanah, 2018) ${ }^{[4]}$ yaknikomponen-komponen kompensasi pendapatan seseorang atau penggajian dalam satu bulan:

1) Gaji Pokok

Gaji pokok merupakan pendapatan dasar yang diterima seseorang karyawan.Penentuan besarnya gaji pokok didasarkan kepada jenjang pendidikan seseorang pada saat masuk. Artinya dengan jenjang pendidikan akan menentukan kepangkatan atau golongan seseorang. Kemudian gaji pokok ini akan naik seiring dengan peningkatan kepangkatannya atau lamanya bekerja.

2) Konsumsi/makan

Uang konsumsi atau uang makan merupakan kompensasi yang diberikan untuk kebutuhan makan dan lauk pauk karyawan.Tunjangan ini juga diberikan untuk anak dan istri yang menjadi tanggungan karyawan.Pembayaran tunjangan konsumsi dapat diberikan dalam bentuk barang atau dikonversi dalam bentuk uang, seharga barang yang diterimanya.

3) Transportasi

Merupakan tunjangan transportasi guna memperlancar karyawan datang ke kantor. Tunjangan transportasi dapat dalam bentuk uang atau kendaraan (motor atau mobil) bagi mereka yang memiliki jabatan tertentu tunjangan transportasi dapat diberikan dalam bentuk kendaraan.

4) Perumahan

Tunjangan perumahan perubahan bantuan perusahaan untuk memperoleh hunian yang layak untuk ditempati.Untuk pemberian tempat hunian atau perumahan dapat diberikan dalam bentuk pembelian rumah, disewa atau diberikan asram.Besarnya tunjangan perumahan yang diterima tergantung dari golongan dan jabatan yang diembannya.

5) Kesehatan

Merupakan tunjangan yang diberikan untuk melindungi karyawan dari sakit.Biasanya tunjangan kesehatan diberikan untuk seluruh keluarga yaitu istri dan beberapa orang anak.Besarnya tunjangan kesehatan tergantung dari golongan dan jabatan seseorang.

6) Tunjangan Jabatan

Tunjangan yang diberikan kepada seseorang yang memperoleh jabatan tertentu.Tunjangan ini diberikan sesuai dengan beban dan tanggung jawab yang diembannya. Artinya begitu karyawan tidak menduduki jabatan, maka tunjangan ini akan segera hilang.

7) Tunjangan Kelangkaan

Merupakan tunjangan yang diberikan kepada seseorang karena keahlian khusus yang dimiliki oleh seseorang dan sangat dibutuhkan oleh perusahaan. Tunjangan 
ini biasanya digunakan sebagai penghargaan atas keahliannya dan untuk menjaga agar karyawan betah dan tidak pindah keperusahaan lain.

8) Tunjangan Kemahalan

Merupakan tunjangan yang diberikan karena kondisi suatu daerah yang biaya hidupnya lebih mahal dibanding daerah lain. Tunjangan ini diberikan agar karyawan mau dipindahkan atau menempati pos dimana dia ditempatkan.Biasanya penempatan di wilayah yang tingkat inflasinya tinggi dibanding dengan daerah lainnya.

9) Tunjangan Inflasi

Merupakan tunjangan yang diberikan ketika kenaikan harga terjadi dalam jangka waktu tertentu.Artinya jika terjadi inflasi $2 \%$ per bulan, maka gaji naik per bulan, namun ketika terjadi deplasi atau penurunan harga, maka tunjangan inflasi tidak dibayar atau bahkan gajinya juga diturunkan sesuai dengan tingkat deplasi.

10) Tunjangan Prestasi

Merupakan tunjangan yang diberikan karena karyawan memperoleh penghargaan tertentu.Biasanya prestasi dalam bentuk penghargaan yang diperoleh dari luar perusahaan atau jasa-jasa karyawan dalam bidang tertentu.

11) Bonus

Merupakan penghargaan atas kinerja karyawan yang dianggap baik, seminggu perlu diberikan penghargaan.Bonus juga dibayarkan karena kinerja perusahaan yang behasil meningkatkan labanya.Jadi bonus hanya dibayar jika perusahaan mengalami keuntungan atau karyawan mampu meningkatkan kinerjanya diatas yang ditargetkan.

12) Insentif

Merupakan upaya perusahaan untuk merangsang atau mendorong karyawan agar mau dan mampu melakukan suatu pekerjaan.Besarnya insentif tergantung dari beban pekerjaan, jenis atau lokasi pekerjaannya.Insentif dapat dibayarkan baik dalam bentuk keuangan maupun non keuangan.

13) Lembur

Merupakan tunjangan perusahaan yang diberikan perusahaan kepada karyawan yang kerja di luar jam kerja atau jam yang telah ditetapkan. Lembur diberikan karena memang pekerjaan tersebut harus segera diselesaikan dan tidak dapat ditunda.Biasanya besarnya lembur dibayar dengan hitungan jam.

14) Tunjangan Hari Tua

Merupakan bentuk penghargaan perusahaan kepada karyawan atas jasa-jasa yang diberikannya selama bekerja.

15) Tunjangan Hari Raya

Merupakan tunjangan yang diberikan pada setiap hari besar keagamaan, misalnya Idul Fitri, Natal dan hari besar lainnya.Besarnya tunjangan hari raya biasanya ditetapkan minimal 1 kali gaji karyawan sesuai fungsi jabatannya.

16) Tunjangan Lainnya

Merupakan tunjangan yang diberikan untuk pekerjaan tertentu, misalnya bagi mereka yang bekerja di laut ada tunjangan uang gelombang.Atau bagi mereka yang bekerja di hutan ada tunjangan uang nyamuk.

\section{Metodologi}

Alat ukur yang digunakan dalam penelitian ini adalah skala kepuasan kerja dan skala kompensasi.Menurut Azwar (2014) ${ }^{[1]}$, skala adalah daftar pernyataan yang akan mengungkap performansi yang menjadi karakter tipikal pada subjek yang diteliti, yang akan dimunculkan dalam bentuk respon-respon terhadap situasi yang dihadapi. Skala dalam penelitian ini memiliki format respon dengan empat alternatif jawaban. Skala yang digunakan dalam penelitian ini menggunakan format respon jawaban model Likert. Menurut 
Sugiyono (2014) ${ }^{[15]}$ skala Likert digunakan untuk mengukur sikap, pendapat, dan persepsi seseorang atau sekelompok orang tentang fenomena sosial.

Sampeladalahbagiandaripopulasi yang menjadiobjekpenelitiandengantujuan agar sampel yang diambildaripopulasinyarepresentativeataumewakilisehinggadapatdiperolehinformasi yang cukupuntukmengestimasipopulasinya(Sugiyono, 2014) ${ }^{[15]}$. Teknik sampling digunakan adalah simple random sampling.Teknik sampling yang digunakan adalah Simple Random Sampling yang berarti pengambilan anggota sampel dari populasi dilakukan secara acak tanpa memperhatikan strata yang ada dalam populasi itu (sugiyono, 2014) ${ }^{[15]}$ Sampel ditentukan dari jumlah populasi tertentu dikembangkan dari Issac dan Michael (dalam Sugiyono, 2014) untuk penentuan jumlah sampel dari populasi tertentu dengan taraf kesalahan $10 \%{ }^{[15]}$.

Jumlah sampel sebanyak78 orang gurupendidik khusus (GPK) Sekolah Inklusif di Kota Padang.

\section{Hasil dan Diskusi}

\subsection{Hasil Try Out Penelitian}

Alat ukur yang telah dirancang oleh peneliti terlebih dahulu dilakukan uji coba atau try outdengan tujuan untuk menyeleksi item-item manakah yang valid dan reliabel agar dapat digunakan dalam penelitian sesungguhnya. Uji coba alat ukur penelitian dilakukan pada tanggal pada tanggal17 Juli 2018 kepada 30 guru pendidik khusus (GPK) Sekolah Inklusif di Kota Padangyang memiliki karakteristik yang sama dengan subjek penelitian.

\section{a. Validitas Skala Kepuasan Kerja}

Koefisien validitas ditetapkan sebesar $\geq 0,30$ sehingga diperoleh hasil dari jumlah aitem awal 40 pernyataan, terdapat 14 item yang gugur sehingga jumlah item yang valid dan reliabel adalah 26 pernyataan, dengan nilai corrected item-total correlation berkisar antara 0,301 sampai dengan 0,755 .

b. Validitas Skala Kompensasi

Koefisien validitas ditetapkan sebesar $\geq 0,30$ sehingga diperoleh hasil dari jumlah aitem awal 48 pernyataan, terdapat 13 aitem yang gugur sehingga jumlah aitem yang valid dan reliabel adalah35 pernyataan, dengan nilai corrected item-total correlation berkisar antara 0,309sampai dengan 0,811.

\section{c. Reliabilitas Skala kepuasan kerjadan Skala Kompensasi}

Reliabilitas skala regulasi diripada penelitian ini menggunakan teknik analisis Alpha Cronbach. Setelah melalui proses penghitungan hasil try out, maka pada skala diperoleh nilai koefisien reliabilitas sebesar 0,917. Hal ini menunjukkan bahwa alat ukur skala kepuasan kerja memiliki reliabilitas yang tinggi.

Hasil uji reliabilitas pada skalaprokrastinasi adakemik melalui teknik analisis Alpha Cronbachdiperoleh koefisien sebesar 0,941.Hal ini menunjukkan bahwa alat ukur skala kompensasimemiliki reliabilitas yang tinggi, sehingga reliabel untuk digunakan dalam penelitian.

\subsection{Hasil Penelitian}

Penelitiandilakukandenganmenyebarkanskala kepuasan kerja dan skala kompensasi. Pengambilan data dimulai pada hari Rabu tanggal 18 Juli 2018. Skala yang telah di isi oleh Guru Pendidik Khusus (GPK) Sekolah Dasar Inklusif di Kota Padang dikembalikan kepada peneliti. 
Sebelum melakukan uji hipotesis terlebih dahulu peneliti melakukan uji asumsi terhadap data hasil penelitian yang meliputi uji normalitas sebaran dan uji linieritas hubungan antar variabel penelitian.

\subsubsection{Uji Normalitas}

Uji normalitas digunakan untuk mengetahui apakah populasi data berdistribusi normal atau tidak. Uji normalitas dalam penelitian ini menggunakan uji Kolmogorov-Smirnov. Data yang dinyatakan berdistribusi normal jika signifikansi (p) lebih besar dari 0,05 . Priyatno $(2008)^{[12]}$ menyatakan bahwa data dinyatakan berdistribusi normal jika signifikansi lebih besar dari 5\% atau 0,05.Berdasarkanhasil pengolahan data dengan menggunakan program IBM SPSS versi 21.0, maka diperoleh hasil sebagai berikut:

Tabel 1 : Uji Normalitas Skala Kepuasan Kerja dengan Kompensasi

\begin{tabular}{|l|c|c|c|c|}
\hline \multicolumn{1}{|c|}{ Variabel } & $\mathrm{N}$ & $\mathrm{KSZ}$ & $\mathrm{p}$ & Sebaran \\
\hline Kompensasi & 78 & 1,039 & 0,231 & Normal \\
\hline $\begin{array}{l}\text { Kepuasan } \\
\text { Kerja }\end{array}$ & 78 & 0,761 & 0,608 & Normal \\
\hline
\end{tabular}

Berdasarkan tabel 1 di atas, maka diperoleh nilai signifikansi pada skala kompensasi sebesar $\mathrm{p}=0,231$ dengan $\mathrm{KSZ}=1,039$ hasil tersebut menunjukan bahwa nilai $\mathrm{p}>0,05$, artinya sebaran skala kompenasi terdistribusi secara normal, sedangkan untuk kepuasan kerja diperoleh nilai signifikansi sebesar $\mathrm{p}=0,608$ dengan $\mathrm{KSZ}=0,761$ hasil tersebut menunjukan bahwa nilai $\mathrm{p}>0,05$, artinya sebaran skala kepuasan kerja terdistribusi secara normal.

\subsubsection{Uji Linieritas}

Uji linieritas bertujuan untuk mengetahui apakah dua variabel mempunyai hubungan yang linier atau tidak. Dua variabel dikatakan mempunyai hubungan yang linier bila signifikansi (Linearity) kurang dari 0,05 (Priyatno, 2008) ${ }^{[12]}$. Berdasarkan hasil pengolahan data dengan menggunakan program IBM SPSS21.0, maka diperoleh hasil sebagai berikut:

Tabel 2 : Uji Linieritas Skala Kepuasan Kerja denganKompensasi

\begin{tabular}{|c|c|c|c|c|}
\hline $\mathrm{N}$ & Df & Mean Square & F & Sig \\
\hline 78 & 1 & 2690,779 & 553,532 & .000 \\
\hline
\end{tabular}

Berdasarkan tabel 2 di atas, diperoleh nilai $\mathrm{F}=553,532$ dengan signifikansi sebesar $\mathrm{p}=0,000(\mathrm{p}<0,05)$, artinya varians pada skala kompensasi dengan kepuasan kerja tergolong linier.

\subsubsection{Uji Hipotesis}

Uji hipotesis bertujuan untuk mengetahui apakah kesimpulan pada sampel dapat berlaku untuk populasi atau dapat digeneralisasi (Priyatno, 2008) ${ }^{[12]}$. Pengolahan data penelitian tentang hubungan antara kompensasi dengan kepuasan kerja Guru Pendidik Khusus (GPK) kepada 78 orang guru Sekolah Dasar Inklusif di Kota Padang menggunakanuji statistic Pearson Product Moment dengan bantuan SPSS 
21,0.Hasil perhitungan uji korelasi Product Moment (Pearson) dengan bantuan SPSS 21,0dapat dilihat pada tabel 3 sebagai berikut :

Tabel3 :Hasil Uji Korelasi Antara Skala SkalaKompensasi dengan Kepuasan Kerja

\begin{tabular}{|c|c|c|c|l|}
\hline $\mathrm{P}$ & $(\alpha)$ & Nilai Korelasi $(\mathrm{r})$ & $\mathrm{R}$ square & \multicolumn{1}{c|}{ Kesimpulan } \\
\hline 0,000 & 0.01 & 0,835 & 0,696 & $\begin{array}{l}\text { sig }(2 \text { - tailed) } 0,000<0,01 \\
\text { level of significant }(\alpha), \text { berarti } \\
\text { hipotesis diterima. }\end{array}$ \\
\hline
\end{tabular}

Berdasarkan tabel di atas, maka diperoleh koefisien korelasi antara kompensasi dengan kepuasan kerja yaitu sebesar $r=0,835$. Hal ini menunjukkan adanya korelasi yang berarah positif, yang artinya semakin tinggi kompensasi maka kepuasan kerja semakin baik. Begitu juga sebaliknya, semakin rendah kompenasi maka kepuasan kerja semakin buruk. Hal ini di perkuat dengan hasil uji signifikan dengan bantuan IBM SPSS 21,0 didapatkan $\mathrm{p}=0,000<0,01$ level of significant $(\alpha)$, sesuai dengan hipotesis diterima, bahwa terdapat hubungan antara Kompensasi dengan Kepuasan Kerja Guru Pendidik Khusus (GPK) di Kota Padang.

Berikut tabel deskriptif statisitik dari variabel kompensasi dan kepuasan kerja berdasarkan Mean Hipotetik sebagai berikut:

Tabel4 :Deskriptif Statisitik Mean Hipotetik

\begin{tabular}{|l|c|c|c|c|c|}
\hline \multicolumn{1}{|c|}{ Variabel } & $\mathrm{N}$ & Mean & Std.Deviation & Minimum & Maximum \\
\hline Kompensasi & 78 & 113,59 & 12,152 & 78 & 124 \\
\hline $\begin{array}{l}\text { Kepuasan } \\
\text { Kerja }\end{array}$ & 78 & 84,51 & 7,083 & 78 & 120 \\
\hline
\end{tabular}

Berdasarkan tabel 4 diatas nilai Mean Hipotetik, maka dapat dilakukan pengelompokkan yang mengacu pada kriteria pengka tegorisasian dengan tujuan menempatkan individu kedalam kelompok-kelompok yang terpisah secara berjenjang menurut suatu kontinum berdasarkan atribut yang diukur (Azwar, 2014) $)^{[1]}$, dengan ketentuan sebagai berikut :

Tabel5 :Norma Kategorisasi

\begin{tabular}{|c|c|}
\hline Norma & Kategorisasi \\
\hline$X<(\mu-1,0 \sigma)$ & Rendah \\
\hline$(\mu-1,0 \sigma) \leq X<(\mu+1,0 \sigma)$ & Sedang \\
\hline$(\mu+1,0 \sigma) \leq X$ & Tinggi \\
\hline
\end{tabular}

Keterangan :

$\begin{array}{ll}\mathrm{X} & : \text { Skor mentah sampel } \\ \mu & : \text { Mean atau rata-rata } \\ \sigma & : \text { Standar Deviasi }\end{array}$ 
Berdasarkan norma diatas, maka diperoleh kategorisasi subjek penelitian pada variabel kompensasi dan kepuasan kerja sebagai berikut:

Tabel6 :Kategori Kompensasi Dengan Kepuasan Kerja

\begin{tabular}{|c|c|c|c|c|}
\hline Variabel & Skor & Jumlah & Persentase (\%) & Kategori \\
\hline \multirow{3}{*}{ Kompensasi } & $78-100$ & 10 & $13 \%$ & Rendah \\
\cline { 2 - 5 } & $101-126$ & 62 & $79 \%$ & Sedang \\
\cline { 2 - 5 } & $127-134$ & 6 & $8 \%$ & Tinggi \\
\hline \multirow{3}{*}{ Kepuasan Kerja } & $70-76$ & 14 & $18 \%$ & Rendah \\
\cline { 2 - 5 } & $77-92$ & 55 & $71 \%$ & Sedang \\
\cline { 2 - 5 } & $93-99$ & 11 & $14 \%$ & Tinggi \\
\hline
\end{tabular}

Berdasarkan tabel di atas dapat digambarkan bahwa ada 13\% Guru yang memiliki kompensasi dengan kategori rendah, 79\% Guru yang memiliki kompensasi dengan kategori sedang dan $8 \%$ Guru memiliki kompensasi dengan kategori tinggi.Sementara itu ada 18\% Guru yang memiliki kepuasan kerja dengan kategori rendah, 71\% Guru yang memiliki kepuasan kerja dengan kategori sedang dan 14\% Guru yang memiliki kepuasan kerja pada kategori tinggi.

\section{Sumbangan Efektif}

Besar sumbangan variabel kompensasi terhadap variabel kepuasan kerja dapat ditentukan dengan menggunakan rumus koefisien determinan. Koefisien determinan adalah kuadarat dari koefisien korelasi yang dikali dengan 100\% (Priyatno, 2018) ${ }^{[12]}$.

Derajat koefisien determinan dicari dengan menggunakan rumus sebagai berikut :

$$
\mathrm{KP}=\mathrm{r}^{2} .100 \%
$$

Keterangan:

$\mathrm{KP}=$ Nilai Koefisien Determinan

$\mathrm{r} \quad=$ Nilai Koefisien Korelasi

$$
\begin{aligned}
\mathrm{KP}=\mathrm{r}^{2} \times & 100 \% \\
& =0,835^{2} \times 100 \% \\
& =0,6972 \times 100 \% \\
& =69,72 \% \\
& =70 \%
\end{aligned}
$$

Berdasarkan rumus tersebut maka dapat ditentukan bahwa besarnya sumbangan kompensasi terhadap kepuasan kerja adalah sebesar $70 \%$ dan $30 \%$ lagi dipengaruhi oleh faktor lain.

Berdasarkan hasil uji korelasi Product Moment (Pearson) yang dilakukan dengan bantuan IBM SPSS versi 21.0, dimana level of significant $(\alpha)$ 0,01 dan diperoleh nilai koefisien korelasi $\left(\mathrm{r}_{\mathrm{xy}}\right)=0,835$ dengan nilai $(\mathrm{p})$ sig $=0,000$, karena nilai $(\mathrm{p})$ sig $0,000<0,01$ maka hipotesis diterima. Hasil ini menunjukkan bahwa terdapat hubungan antara kompensasi dengan kepuasan kerja Guru Pendidik Khusus (GPK) Sekolah Dasar Inklusif di Kota Padangdengan arah positif. Artinya semakin tinggi kompensasi maka kepuasan kerja semakin baik. Begitu juga sebaliknya, semakin rendah kompensasiGuru Pendidik Khusus (GPK) Sekolah Dasar Inklusif di Kota Padang maka kepuasan kerja semakin buruk. 
Menurut pendapat dari Mangkunegara (dalam Tanhowi 2014) ${ }^{[16]}$ kompensasi yang diberikan kepada pegawai sangat berpengaruh pada tingkat kepuasan kerja dan motivasi kerja, serta hasil kerja. Memberikan kompensasi yang sesuai dengan jenis pekerjaan dan jabatan kerja, maka pendidik akan merasakan kepuasan dalam bekerja.Kesalahan dalam menerapkan sistem kompensasi akan berakibat timbulnya demotivasi dan tidak adanya kepuasan kerja di kalangan pekerja Keyakinan bahwa karyawan yang puas akan membawa dampak yang baik bagi perusahaan, menjadikan kepuasan kerja sebagi hal yang diperhatikan perusahaan. Pemberian kompensasi kepada karyawan dapat memotivasi dan memberikan kepuasan kerja (Wibowo, dalam Tanhowi,2014) ${ }^{[16]}$.

Kompensasi memberikan kontribusi terhadap kepuasan kerja sebesar 70\%. sedangkan 30\% sisanya dipengaruhi oleh faktor-faktor lain. Menurut Mangkunegara (dalam Krisdina, $2008)^{[7]}$, faktor lain yang mempengaruhi kepuasan kerja yaitu faktor yang ada pada diri pegawai dan faktor pekerjaannya. Faktor pegawai yaitu kecerdasan, kecerdasan khusus, umur, jenis kelamin, kondisi fisik,pendidikan, pengalaman kerja, masa kerja, kepribadian, emosi, cara berpikir, persepsi dan sikap kerja. Faktor pekerjaan yaitu jenis pekerjaan, skruktur organisasi, pangkat (golongan), kedudukan, mutu pengawasan, jaminan finasial, kesempatan promosi jabatan, interaksi social dan hubungan kerja.

Berdasarkan hasil penelitian maka didapatkan hasil bahwa ada $13 \%$ Guru yang memiliki kompensasi dengan kategori rendah, 79\% Guru yang memiliki kompensasi dengan kategori sedang dan $8 \%$ Guru memiliki kompensasi dengan kategori tinggi.

Sementara itu ada 18\% Guru yang memiliki kepuasan kerja dengan kategori rendah, 71\% Guru yang memiliki kepuasan kerja dengan kategori sedang dan $14 \%$ Guru yang memiliki kepuasan kerja pada kategori tinggi.

\section{Kesimpulan}

Berdasarkan hasil analisis data kuantitatif yang diperoleh melalui penelitian ini maka dapat diperoleh kesimpulan bahwa hubungan antara kompensasi dengan kepuasan kerja Guru Pendidik Khusus (GPK) Sekolah Dasar Inklusif dengan arah positif dan signifikan. Terlihat dari hasil korelasi antara antara kepuasan kerja dengan kompensasi pada Guru Pendidik Khusus (GPK) Sekolah Dasar Inklusif di Kota Padang dengan arah positif, artinya hipotesis diterima jika kompensasi tinggi, maka kepuasan kerja guru akan baik, sebaliknya jika kompensasi diberikan rendah, maka kepuasan kerja guru akan buruk.

Besarnya sumbangan efektif dari variabel kompensasi dengan kepuasan kerja pada Guru Pendidik Khusus (GPK) Sekolah Dasar Inklusif di Kota Padang adalah sebesar 70\%.

\section{Referensi}

[1] Azwar, Syaifudin. 2014. Penyusunan Skala Psikologi. Yogyakarta: Pustaka Pelajar.

[2] Ashar, Suyoto, Munandar. 2008.Psikologi Industri dan Organisasi. Jakarta: UI Press.

[3] Devi, Afrina Marti. 2012. Pendidikan Inklusif Disekolah Dasar Kota Padang. Jurnal Ilmiah Pendidikan Khusus. Vol 1 No. 3, September 2012. Padang: Jurusan Pendidikan Luar Biasa FIP Universitas Negeri Padang.

[4] Hasanah, Uswatun. 2018. Hubungan Antara Kompensasi Dengan Work Engagement Pada Pekerja Bagian Aspal di PT. KSO Yasa Conbloc. (Skripsi tidak dipublikasikan). Padang: Fakultas Psikologi Universitas Putra Indonesia 'YPTK'.

[5] Huroiyati, Anita \& Pramesti Pradna Paramitha. 2015. Studi Deskriptif Sikap Guru terhadap Pendidikan Inklusi di SMP Negeri Inklusi Se-Surabaya. Jurnal Psikologi Pendidikan dan Perkembangan. Vol 4 No. 1 April 2015. Surabaya: Fakultas Psikologi Universitas Airlangga. 
[6] Kasmir. 2016. Manajemen Sumber Daya Manusia. Jakarta: Rajawali.

[7] Krisdina, Oktavia. 2008. Pengaruh Kompensasi Terhadap Kepuasan Kerja Guru Theresiana. Skripsi. Semarang: Jurusan Manajemen Fakultas Ekonomi Universitas Katolik Soegijapranata.

[8] Kurniawan, Harri \& Ade Suryani. 2018. Hubungan Antara Keterlibatan Kerja Dengan Kepuasan Kerja Karyawan PT. Dharmasraya Lestarindo Kab. Dharmasraya. Jurnal Psyche 165. Vol. 11. No. 1 Januari 2018 Hal. 11-20. Padang: Universitas Putra Indonesia 'YPTK' FakultasPsikologi.

[9] Latama, Yogie. 2018. Hubungan Antara Kompensasi Dengan Loyalitas Driver (Pengemudi) di PT.MIA Tour And Travel kabupaten Pesisir Selatan. (Skripsi tidak dipublikasikan). Padang: Fakultas Psikologi Universitas Putra Indonesia 'YPTK'.

[10] Laylatul, Deni Zakia. 2015. Guru Pendidik Khusus (GPK) : Pilar Pendidikan Inklusi. Skripsi. Surakarta: Magister Pendidikan Luar Biasa Universitas Negeri Surakarta.

[11] Pratiwi, Jamilah Candra. 2015. Sekolah Inklusi untuk Anak Berkebutuhan Khusus: Tanggapan Terhadap Tantangan Kedepannya. Jawa Tengah: Universitas Sebelas Maret Surakarta.

[12] Priyatno, Dwi. 2008. Mandiri Belajar SPSS untuk Analisis Data dan Uji Statistik. Jakarta: Mediakom.

[13] Retnoningsih, Teguh, dkk. 2016. Pengaruh Kompensasi terhadap Kepuasan Kerja dan Kinerja Karyawan (Studi pada Karyawan PT PLN Persero Distribusi Jawa Timur area Malang). Jurnal Administrasi Bisnis. Vol 35 No. 2 Juni 2016. Malang: Fakultas Ilmu Administrasi Universitas Brawijaya.

[14] Savana, Putri Angelina. 2018. Hubungan Psychological Capital dengan Kepuasan Kerja Pada Perawat di RSUD Padang Pariaman. (Skripsi tidak dipublikasikan). Padang: Fakultas Psikologi Universitas Putra Indonesia 'YPTK'.

[15] Sugiyono. 2014. Metode Penelitian Kualitatif dan Kuantitatif. Bandung: CV Alfabeta

[16] Tanhowi, Imam. 2014. Pengaruh Kompensasi terhadap Kepuasan Kerja Guru Tetap Definitif SD Islam Al-Ahar 17 Bintaro. Epigram. Vol 11 No. 1, April 2014: 71-78. Jakarta: Program Studi Administrasi Bisnis Terapan Jurusan Administrasi Niaga Politeknik Negeri Jakarta.

[17] Utina, Sitriah Salim. 2014. Pendidikan Anak Berkebutuhan Khusus. Jurnal Manajemen Pendidikan Islam. Vol 2 No. 1 Februari 2014. Gorontalo: IAIN Sultan Amai.

[18] Gusman, A. P., \& Kurniawan, H. (2018). FUZZY LOGIC DALAM MENGANALISA PENGARUH KONSEP HALAL TOURISM TERHADAP PERILAKU MASYARAKAT SUMATERA BARAT. Jurnal Matematika UNAND, 7(2). 